\title{
TRANSFORMASI GERAKAN EKONOMI ISLAM KONTEMPORER
}

\author{
Asep Saepudin Jahar \\ Fakultas Syariah dan Hukum UIN Syarif Hidayatullah \\ Jl. Ir. H. Juanda No. 96 Tangerang, Banten, 15412 \\ e-mail: asepjahar@uinjkt.ac.id
}

\begin{abstract}
Abstrak: Tulisan ini membahas fenomena gerakan ekonomi Islam Indonesia sejak masa awal kemerdekaan hingga reformasi. Ditemukan dalam literatur dan bukti sejarah bahwa gerakan ekonomi Islam mengalami perubahan orientasi dari masa awal kemerdekaan hingga saat ini. Misi gerakan masa awal lebih menonjolkan semangat nasionalisme dan keagamaan dengan melibatkan kelompok Islam dan ormas. Sementara pada awal 1990an dan pasca reformasi, gerakan ekonomi Islam lebih kepada kesadaran sosial ekonomi dan pasar global, bukan Islamisasi. Kemiskinan dan ketertinggalan dalam pendidikan adalah bagian penting misi ini. Selain itu, gerakan ekonomi Islam juga menekankan entrepreneurship untuk pengembangan masyarakat. Karena itu pendirian bank syariah dan lembaga-lembaga filantropi menjadi bagian dari kesadaran untuk mengembangkan masyarakat Muslim. Dalam perkembangannya, semangat keislaman ini melebur pada konteks demokratisasi yang menekankan transparansi dan akuntabilitas, bukan semata-mata keagamaan. Karena itu, model gerakan ekonomi diarahkan pada pemberdayaan masyarakat dan kesejahteraan.
\end{abstract}

\begin{abstract}
The Transformation of Contemporary Islamic Economics Movement. This paper discusses the phenomenon of Islamic movements in Indonesian since the post-independence until the reformation time. It argues that there is a transformation of Islamic economic movement from the post-Independent (19451998) which emphasizes nationalism and religiosity to community development in the post reformation era. In the early 1990s and after the reformation era, the movement of Islamic economics is aimed at improving social, education and economic development among the poor, not Islamization. In addition, the movement of Islamic economy also emphasizes entrepreneurship for the development of society. The establishment of Islamic banks and philanthropic institutions become the main part of developing Muslim community. In its development, Islamic spirit goes hand in hand with democratization that emphasizes transparency and accountability. Therefore, the model of economic movements aims at community empowerment and welfare.
\end{abstract}

Kata Kunci: Islamisasi, filantropi Islam, ekonomi Islam, demokratisasi, reformasi 


\section{Pendahuluan}

Gerakan ekonomi Islam di Indonesia sejak pra-kemerdekaan hingga kini memiliki corak yang beragam. Namun gerakan ini menggambarkan misi-misi nasionalisme, solidaritas keagamaan dan Islamisasi. Pada masa pra dan menjelang kemerdekaan, konfrontasi dengan pemerintahan kolonial Belanda memunculkan sentimen nasionalisme dan keagamaan. Nasionalisme diarahkan sebagai respons terhadap kolonialisme Belanda yang bertindak diskriminatif terhadap pribumi. Sentimen agama digunakan sebagai gerakan solidaritas komunitas Muslim terutama di Jawa dan Sumatera untuk membangkitkan kesatuan keagamaan dan kemerdekaan. Pasca kemerdekaan hingga reformasi, gerakan ekonomi Islam lebih kental dengan dinamika kapitalisasi organisasi keagamaan untuk kesejahteraan umat dan dakwah, seperti Muhammadiyah, Persis dan Nahdlatul Ulama.

Pasca 1990an semangat Islamisasi mulai menguat yang didasari dua hal: pertama, kesulitan akses pada sumber daya ekonomi, terutama karena dominasi asing dan Cina; kedua, pencarian identitas keislaman dalam gerakan ekonomi, utamanya untuk memperkuat solidaritas dan Islamisasi yang disebabkan menguatnya kapitalisme di kalangan kelas penguasa (elite). Gerakan BMT, Bank Islam dan lembaga-lembaga filantropi Islam pada akhir 70an hingga saat ini dapat dipahami untuk merespons fenomena itu. Semangatnya yaitu untuk merespons pasar dan gerakan pemberdayaan masyarakat yang bercirikan semangat keislaman baru untuk kesejahteraan dan kebangkitan dari kebodohan (pendidikan). Tulisan ini hanya akan membahas gerakan ekonomi Islam Indonesia modern, tepatnya awal abad ke-20 dengan perspektif sistem entrepreneurship sosial. ${ }^{1}$

Merujuk pada penjelasan sejarawan dan para Indonesianis, fenomena gerakan ekonomi Indonesia tidak bisa dilepaskan dari pengaruh sosial politik yang berlangsung. Sistem politik pemerintah Hindia Belanda, para agen kekuatan ekonomi non-pribumi yang diberikan privilege (China), budaya dan agama sangat mewarnai gerakan ini. Namun, jika dibaca secara detail, gerakan ekonomi Islam dapat diklasifikasikan kepada dua tipe: pertama, masa pra-kemerdekaan, model gerakan ekonomi lebih bercirikan religius nasionalisme terutama dalam kontestasi persaingan bisnis dengan kelompok non-pribumi seperti China dan Arab yang diberikan ruang lebih istimewa oleh Pemerintahan Kolonial; kedua, pasca kemerdekaan yaitu masa konsolidasi kelompok agama seperti Muhammadiyah dan NU serta lembaga-lembaga sosial ekonomi dengan pendirian BMT dan lembaga-lembaga ZISWAF

${ }^{1}$ Sri Rahayu Hijrah Hati dan Aida Idris," the Social Movement and Social Enterprise Development in the Emergence of Indonesia 1895-1945 in Univeristy of Malaya" (paper online), h. 1-3. Merujuk pada tulisan Hati dan Idris yang juga mengutip pendapat Professor Gregory Dees, pendiri Duke University's Centre for the Advancement of Social Entrepreneurship, Social Entrepeneurship berarti aktivitas organisasi yang difokuskan untuk memenuhi misi sosial dengan melakukan inovasi dan strategi problem-solving dengan menununjukkan akuntabilitas publik. Istilah ini juga dianggap berbeda dari gerakan NGO dalam pengertian bahwa ia adalah lembaga mendapatkan income-nya dari aktivitas perdagangan (jual-beli) dan bebas dari pengaruh pemeintah (Lyon \& Sepulveda, 2009). 
(zakat, infak, wakaf dan shadaqah). Pada kasus kedua ini, gerakan ekonomi berbarengan dengan diseminasi ajaran dan ideologi organisasi, walaupun semangat kesejahteraan ekonomi dan peningkatan taraf pendidikan masyarakat masih dijadikan kegiatan utama.

\section{Nasionalisme dan Ekonomi}

Gerakan ekonomi Islam Indonesia pada masa awal abad 20 bercirikan nasionalismekeagamaan. Gerakan ini utamanya didorong oleh kelompok saudagar Muslim yang mencapai klimaksnya ketika didirikannya Sarekat Dagang Islam di Betawi tahun 1909 dan diikuti oleh Sarekat Dagang Islam di Surakarta tahun 1911 oleh RM. Tirtoadisoerjo dan berganti nama menjadi Sarekat Islam pada tahun 1913. Sebagai organisasi non-politik, SI memiliki kegiatan utama pada bidang sosial dan ekonomi. Usaha-usaha SI untuk mendorong tumbuhnya kesejahteraan masyarakat dan keadilan ekonomi cukup penting terutama ketika persaingan dalam ekonomi menguat dimana pribumi mulai tersingkir. Salah satu alasan berdirinya organisasi ini, selain hegemoni kolonial Belanda, adalah menguatnya kekuatan Cina dalam sistem perdagangan, sedang pribumi (Islam) sangat terbelakang khususnya dalam persaingan perusahaan batik di daerah Surakarta. Kekuatan Cina dalam usaha batik ini yang berhasil menguasai bahan-bahan impor menumbuhkan kesadaran pribumi yang dimotori oleh Haji Samanhoedi dengan mendirikan Sarekat Islam di Surakarta (Solo). ${ }^{2}$ Pada perkembangan selanjutnya organisasi ini tidak saja diikuti oleh kaum pedagang tetapi juga oleh kalangan priyayi, petani dan militer. Kehadiran SI disamping sebagai awal kesadaran keagamaan (umat) para pedagang Muslim juga didorong oleh usaha untuk melawan dominasi Cina yang mendapatkan hak-hak istimewa dari pihak kolonial Belanda. Misi gerakan sosial, ekonomi dan keagamaan Sarekat Islam kemudian dikembangkan oleh tokoh yang sangat berpengaruh, yaitu Cokroaminoto dan Agus Salim. Kedua tokoh ini banyak mengenyam pendidikan Hindia Belanda yang kemudian menjadi motor penggerak timbulnya kesadaran nasionalisme atas tekanan kolonial.

Beberapa tempat seperti Kotagede di Yogyakarta, Laweyan di Surakarta dan Kauman di Kudus adalah pusat-pusat perniagaan yang cukup menonjol pada masa itu. ${ }^{3}$ Kebangkitan ekonomi Islam pada masa ini juga didorong dengan mulai menguatnya kelompok Muslim dengan pola religio-economic development. Tipe gerakan borjuis ini ditopang oleh pribumi yang terdiri atas pengusaha dan cendekiawan. Pertekstilan dan batik menjadi komoditas perdagangan yang utama saat itu, ditambah dengan industri rokok seperti ditemukan di daerah Jawa Tengah dan Jawa Timur. Pesaing utama usaha tekstil adalah Cina dan barangbarang impor dari luar negeri. Tegal, Semarang, Surakarta, Yogyakarta, Surabaya, Kediri dan

${ }^{2}$ George D. Larson, Masa Menjelang Revolusi (Yogyakarta: Universitas Gadjah Mada, 1990), h. 53-54.

${ }^{3}$ Mitsuo Nakamura, The Crescent Arises over the Banyan Tree (Yogyakarta: Percetakan UGM, 1983), h. 55. 
Tulungagung menjadi basis home industry tekstil. Model home industry ini menandakan bahwa manufaktur dan pabrik masih menjadi milik modal asing. ${ }^{4}$ Berhadapannya pribumi dan non-pribumi (kolonial) membangkitkan kesadaran keagamaan dan kebangsaan bagi komunitas Jawa saat itu. Disamping perdagangan, kebangkitan komunitas Muslim juga didorong oleh faktor pendidikan, terutama bagi kelompok bangsawan (priyayi) yang memiliki peluang untuk diangkat sebagai pegawai negara dan perusahaan swasta.

Berbeda dengan Jami'atul Khair (berdiri 1905) yang eksklusif bagi warga keturunan Arab dan Budi Utomo (berdiri 1908) yang eksklusif bagi priyayi Jawa, SI menjadi organisasi massa pertama yang terbuka. ${ }^{5}$ Kehadiran SI juga sebagai respons atas kesenjangan sosial antara pribumi dan kolonial, juga antara Cina dan pribumi. Kehadiran SI juga disebabkan persaingan batik di Jawa antara Cina dan pribumi. ${ }^{6}$ SI bertujuan memajukan umat Islam, memajukan persatuan dan kerja sama, memadukan negeri, meningkatkan kedudukan bumiputra dan memajukan kehidupan keagamaan di kalangan bumiputera Indonesia. ${ }^{7}$ Seperti dijelaskan di awal bahwa kesadaran pentingnya akses ekonomi bagi pribumi, dalam kongres ke-15 tahun 1928, PSI mencoba mendirikan Bank Nasional untuk membentuk kesadaran rakyat tentang cita-cita kebangsaan serta independen dari pemerintahan kolonial. ${ }^{8}$ Walaupun masih berdasar pada model bunga, lembaga keuangan bertujuan untuk meningkatkan martabat masyarakat dalam ekonomi. Gerakan struktural ekonomi masa itu lebih melihat keadaan ekonomi masyarakat pribumi yang tertinggal karena dominasi dan kebijakan diskriminasi pemerintah kolonial Belanda. Isu nasionalisme terlihat lebih ditonjolkan walaupun para penggagas ini muncul dari kelompok gerakan al-Islam. ${ }^{9}$

Gerakan modernis Islam di Minangkabau pada awal abad ke-19 bukan saja menampilkan kontestasi agama atas adat, tetapi juga kesadaran bisnis dengan dunia luar, terutama Cina dan Arab. Modernisasi agama ${ }^{10}$ ini berimbas pada dinamisasi ekonomi sebagai sumber

${ }^{4}$ Mitsuo Hiroshi, The Development of Javanese Cotton Industry (Tokyo: The Institute of Developing Economics, 1970). Lihat juga Kuntowijoyo, Paradigma Islam (Bandung: Mizan, 1998), h. 79.

5Wardini Ahmad, "Kongres al-Islam 1922-1941" (Disertasi: IAIN Syarif Hidayatullah Jakarta, 1989), h. 41. Disebutkan bahwa organisasi ini adalah organisasi modern pertama yang menjadi wadah umat Islam yang terbuka.

${ }^{6}$ Lihat juga kutipan Wardini dari APE Korver, Sarekat Islam Gerakan Ratu Adil? (Jakarta: Grafiti Press, 1985), h. 11-12.

${ }^{7}$ Ahmad, "Kongres al-Islam 1922-1941," h. 43. Keanggotan SI tidak membatasi diri dari suku dan daerah tertentu, tetapi terbuka untuk semua golongan. Misi didirikan Sarekat Islam tertuang dalam Anggaran Dasarnya, yaitu bertujuan untuk memajukan perdagangan, menolong anggota-anggotanya yang susah, memajukan kehidupan keruhanian, meluruskan pendapatpendapat yang salah tentang Islam, memajukan kehidupan keagamaan sesuai dengan hukum dan kebiasaan Islam. Disebutkan juga, seperti ditegaskan Pijper bahwa kekuatan Sarekat Islam sangat menonjol di masyarakat sebelum ia meleburkan diri menjadi partai. Setelah masuk menjadi partai politik gerakan Sarekat Islam lambat laun pengaruhnya menurun.

${ }^{8}$ Ahmad, Kongres al-Islam, h. 304.

${ }^{9}$ Ibid., h. 308.

${ }^{10}$ Para tokoh modernisasi agama di tanah Minang misalnya, Sjech Ahmad Chatib (1855- 
daya penting aktivitasnya. Gerakan ekonomi saat itu terlihat jelas bahwa nasionalisme menjadi inspirasinya. Saudagar Muslim Jawa, Minangkabau dan Bugis dikenal sebagai kaum pedagang yang handal dalam berbisnis. Bentuk usaha dagang dan pertanian sangat menonjol saat itu. ${ }^{11}$

Di pulau Jawa, aktivitas ekonomi Muslim dalam bentuk perdagangan banyak dijumpai pada komunitas Kauman, yaitu orang-orang "kelompok pilihan" di tengah daerah khusus, utamanya sekeliling Masjid Agung Yogyakarta. Istilah "Kauman" dinisbatkan pada kelompok elite kecil dari orang beragama yang saleh dalam beribadah. Komunitas model kauman ini juga tumbuh di Kudus, terutama di sekitar Masjid Kudus. Di sinilah kelompok kauman diidentikan konservatif dan tetap mempertahankan identitasnya.

Pengaruh migran Hadramaut juga membangkitkan gerakan ekonomi Islam di Jawa, seperti produksi kopra, penanaman tembakau, karet, industri batik dan rokok kretek. Dari sini berkembang perusahan kelompok santri: kelapa di Jawa Barat (Banten), perkebunan tembakau di Jawa Tengah, Jawa Timur dan Madura, karet di Jawa Barat, Sumsel dan Kalimantan; batik di Yogyakarta dan Pekalongan, dan rokok kretek di Kudus. Khusus batik dan kretek menjadi home industry yang bisa berkembang tanpa bantuan bank. Pengaruh Timur Tengah terutama ketika pergi haji ke Makah juga mendorong pergerakan ekonomi Muslim.

Gerakan ekonomi di Jawa Barat, Purwokerto $1895^{12}$ dengan koperasi untuk tujuan kredit dan produksi sebagai dukungan perusahaan dan penyaluran barang. Di Pasundan tahun 1911 untuk melawan pedagang Cina yaitu dengan memadukan pendidikan dan ekonomi. Perhimpunan ini kemudian menjadi Persarikatan Ulama yang didirikan oleh Hadji Abdul Halim. ${ }^{13}$ Hayat al-Qulûb, adalah organisasi yang didirikan Halim untuk fokus pada ekonomi dan pendidikan. Iuran dari anggotanya seperti pedagang dan petani sekitar 5 sen setiap minggu digunakan untuk membantu usaha penenunan sebagai respons

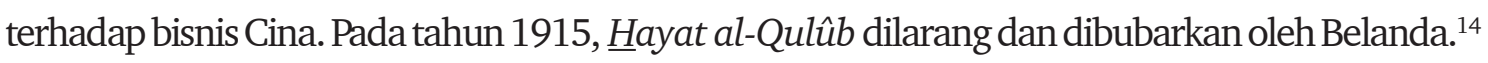
Pergerakan ini hanya terbatas di Jawa Barat, Tegal dan Sumatera Selatan. ${ }^{15}$ Di Bandung pada tahun 1923 Persis berdiri dengan bantuan pedagang dari Sumatera, yaitu Haji Zamzam dan Haji Muhammad Junus dan kemudian Ahmad Hasan, asal Tamil lahir di Singapura 1887. Selain itu Muhammad Natsir, yang kemudian menjadi tokoh Masjumi, juga bergabung dengan Persis. ${ }^{16}$

1916), Sjech Muhammad Djamil Djambek (1860-1947), Hadji Abdul Karim Amrullah (18791945) dan anaknya Haji Abdul Malik Karim Amrullah (1908-1981) atau dikenal dengan Hamka.

${ }^{11}$ Denys Lombard, Nusa Jawa: Silang 2 (Jakarta: Gramedia, 2008), h. 104.

${ }^{12}$ Pendirian koperasi ini atas inisiatif pegawai Belanda WPD de Wolff van Westerrode untuk melipatgandakan koperasi kredit pertanian. Lombard, Nusa Jawa: Silang, h. 115.

${ }^{13}$ Lihat juga Deliar Noer, The Modernist Muslim Movement in Indonesia 1900-1942 (Kuala Lumpur: Oxford University Press, 1978), h. 69-70. Diskusi intelektual dan politik sering dilakukan Halim bersama teman-temannya terutama dari Sumatera. Pemikiran dan gerakan 'Abduh dan 
Seperti diuraikan di atas, kehadiran Sarekat Dagang Islam ${ }^{17}$ oleh Haji Samanhoedhi tahun 1911 perlu menjadi catatan penting, karena organisasi ini menjadi cikal bakal gerakan nasionalisme yang cukup penting, terutama dalam merespons ekspansi dan dominasi perdagangan batik Cina. Pendirian perhimpunan bertujuan: pertama, persaingan usaha batik dengan Cina dan superioritasnya terhadap pribumi berkat keberhasilan Revolusi Cina tahun 1911 dan tekanan yang dialami oleh masyarakat dari kelompok bangsawan (elite) Solo. ${ }^{18}$ SDI juga bertujuan untuk memperkuat pengusaha lokal dan menentang gaya feodal yang dipraktikkan para pejabat pemerintah pada masa kolonial Belanda. ${ }^{19}$ Disamping itu asosiasi ini juga berupaya menyatukan semua pedagang dan pengusaha Muslim lokal tanpa membedakan suku. ${ }^{20}$

Persaingan tekstil dan pertenunan dengan Cina sangat kuat terutama dalam hal akses, mulai dari bahan mentah hingga penguasaan pasar. Di Pekalongan, pengusaha pribumi dari Jawa dan Sumatera menguasai pasar batik yang menjangkau pangsa pasarnya hingga ke luar Jawa. Perkebunan kelapa dan kopi juga ditemukan di Banyumas. Namun dalam banyak hal, kemampuan pribumi dalam bisnis masih kalah saing dengan Cina. Disamping akses pada pasar dan bahan mentah, struktur keluarga dan budaya juga sangat berpengaruh pada penguasaan kapital. Disamping asosiasi dan solidaritas kelompok Cina cukup kuat, sistem garis keturunan dalam mempertahankan bisnis juga melestarikan budaya bisnis mereka. Hal inilah yang membedakannya dengan pribumi, dimana dinasti bisnis belum membudaya, sehingga sistem bisnis biasanya terpecah dan melemah karena dibagi diantara keturunan dan ahli waris sepeninggal leluhur (orang tua) yang membangun perusahaan. Keterbelakangan pengusaha pribumi dalam sektor industri dan perdagangan lebih disebabkan oleh mentalitas priyayi, ${ }^{21}$ aset kekayaan lebih banyak diperebutkan oleh ahli waris (generasi)

Jamaluddîn al-Afghanî menjadi isu penting dalam pemikiran dan gerakan Halim. Usaha pembaharuannya dalam pendidikan mengangkat orang non-priyayi untuk terlibat dalam masyarakat.

${ }^{14}$ Ahmad, Kongres al-Islam, h. 56.

${ }^{15}$ Lombard, Nusa Jawa: Silang, h. 115; Lihat juga mengenai Persarikatan Ulama dalam Noer, the Modernist Muslim Movement, h. 69-73.

${ }^{16}$ Lombard, Nusa Jawa: Silang, h. 116.

${ }^{17}$ Kegiatan bisnis SDI di Batavia yaitu penyewaan hotel dan toko perdagangan yang hasilnya digunakan untuk membiayai sekolah dan masyarakat. Di Surabaya, usaha SDI juga serupa yaitu pengumpulan dana dari anggota dikembangkan menjadi koperasi yang menjual makanan pokok dan barang-barang murah. Pada tahun 1913, SDI telah memiliki 10 pusat perdagangan. Lihat juga catatan A.P.E. Korver, Sarekat Islam: Gerakan Ratu Adil? (Grafitipers, 1985).

${ }^{18}$ Lihat Noer, the Modernist Muslim Movement, h. 102. Raden Mas Tirtoadisurjo juga mendirikan Sarekat Dagang Islamiyah di Bogor 1911. Salah satu tujuan pendiriannya yaitu untuk mewujudkan kesejahteraan, kemakmuran, dan keunggulan Indonesia.

${ }^{19}$ Sri Rahayu Hijrah Hati dan Aida Idris, "the Social Movement and Social Enterprise Development in the Emergence of Indonesia, 1895-1945, University Malaysia, h. 4. Paper ini didapat dari download internet, namun tidak ditemukan penerbit jurnal dan tahun penulisannya.

${ }^{20} I b i d .$, h. 5. Lihat juga catatan Rahayu dari F. V. D. Mehden (ed.), Oxford Bibliographies Online, Islamic Studies, 2009.

${ }^{21}$ Sering disebutkan bahwa priyayi masih menganggap perdagangan dan pedagang rendah 
sehingga terpecah dan melemah karena perebutan hak ${ }^{22}$ dan membatasi untuk menggunakan jasa bank untuk ekspansi usaha sehingga cenderung menyimpan uangnya di rumah.

Dalam perkembangan selanjutnya, terutama menjelang dan awal kemerdekaan, usaha-usaha pengembangan ekonomi Islam dilakukan para aktivis Masjumi (Majlis Sjuro Muslimin Indonesia) yang didirikan tahun 1943, seperti Sjafruddin Prawiranegara (1. 1911), Prawoto Mangkusasmito (1. 1910), Muhaammad Roem (1. 1908) serta Kasman Singodimejo (1908). ${ }^{23}$ Visi ekonomi Masjumi menginginkan perkembangan ekonomi yang bebas dan sehat dengan modal nasional untuk merespons persaingan bisnis secara luas, khususnya dengan pengusaha Cina. ${ }^{24}$ Salah satu asosasi yang didirikan Sjafruddin bersama temantemannya di atas adalah Himpunan Usahawan Muslim Indonesia (HUSAMI) pada 24 Juli 1967 yang bertujuan untuk mempelajari dan mengembangkan ajaran dan aturan Islam dalam bidang keuangan dan ekonomi, membantu dan memperkuat usaha-usaha dalam bidang ekonomi umat Islam juga membantu melayani dan membantu pembangunan Negara serta rakyat Indonesia. ${ }^{25}$ Gerakan bisnis HUSAMI masuk pada sektor haji dan ekspor-impor dan pendirian Bank Pembangunan, walaupun akhirnya mengalami kekurangan dana.

Disamping kegiatan praktis, perdebatan teoretis filosofis tentang riba juga berlangsung pada saat itu, utamanya dalam merespons bagaimana tentang kehalalan bunga bank. Pada tahun 1968 diadakan seminar untuk mendiskusikan keterlibatan umat Islam dalam politik pembangunan dan bisnis. Isu tentang riba juga didiskusikan dan mengemuka pandangan tentang halalnya bank sehingga umat Islam bisa mendapatkan dana pinjaman untuk bisnis. ${ }^{26}$ Seminar ini diprakarsai oleh Jajasan Dana Bantuan Untuk Tjalon Hadji Indonesia (JDBTHI).

sementara pendapatan yang diperoleh dari bunga investasi lebih diminati namun kurang berani dalam investasi modal.

${ }^{22}$ Contoh kasus pengusaha sukses pribumi adalah Nitisemito, raja kretek dari Kudus. Pasca pengelolaan oleh Nitisemoto terjadi perebutan hak oleh Soemaji (anak), Karmain (menantu) dan Akwan Markoem (cucunya). Lombard, Nusa Jawa: Silang, h. 118.

${ }^{23}$ Ketiga terakhir adalah ahli hukum tetapi terlibat dalam dalam pengembangan kebijakan usaha. Disebutkan bahwa Prawoto pernah menjabat sebagai Komisaris Garuda Indonesia 19561960, kepala dewan pendanaan DDII (Dewan Dakwah Islam Indonesia), ketua Yayasan Gerakan Islam. Lombard, Nusa Jawa: Silang, h. 119, dan lihat juga terutama catatan kakinya h. 419.

${ }^{24}$ Lombard, Nusa Jawa: Silang, h. 118.

${ }^{25}$ Pipip Achmad Rifai Hasan, "Islam, Social Justice and Economic Development: A Study of the Works of Sjafruddin Prawiranegara" (Disertasi: Concordia University Montreal, 2012), h. 186. Lihat juga Lombard, Nusa Jawa: Silang, h. 119-120.

${ }^{26}$ Lombard, Nusa Jawa: Silang, h. 120, lihat juga catatan kaki 568 yang menjelaskan tentang perdebatan bunga bank. Diskusi panjang pada tahun 1972 dalam majalah Pandji Masjarakat No. 105 tahun 1972 oleh Marzoeki Jatim, "Bank Islam"; MS Ahmad, "Bank Islam di Abadi, Desember 1972, Sjech Ali Hasan Ahmad Addury, Bunga Deposito dalam Bank, Bandung 1972, disimpulkan halal atau makruh. Prof. Mr. Kasman Singodimedjo menjelaskan bahwa bunga itu bukan riba dan bank itu tidak haram, Bandung, stensilan 1972 dari kutipan M Kamal Hasan, h. 90. 


\section{Social Entrepreneurship Masa Orde Baru}

Pada masa Orde Baru segala aktivitas Islam (Muslim) termasuk ekonomi selalu mendapat kontrol dari negara. Strategi Orde Baru untuk memperhalus pendekatannya mensyaratkan segala aktivitas masyarakat selalu dalam kerangka program pemerintah sebagai penopang desain pembangunan yang dicanangkan Soeharto. Kerangka bangun kebijakan ini, yaitu model idealisme untuk memperkokoh Pancasila dan UUD 1945 sebagai landasan ideologis negara. ${ }^{27}$ Dari sinilah kemudian, gerakan ekonomi kelompok Muslim perlu beradaptasi dengan regulasi sosial, ekonomi dan politik yang dibangun Soeharto. Secara politis, aktivitas ekonomi dengan pola seperti ini dapat berkontribusi dalam menjaga kestabilan dan kepentingan politik Soeharto yang sedang berlangsung. Ideologi non-Pancasia seperti sosialis, kapitalis dan komunis dilarang tumbuh; sementara Islam, walaupun pada tahun 1970an dan 1980an dikontrol ketat, pada sepuluh tahun akhir masa kekuasaannya lebih ditempatkan sebagai bagian yang lebih kompromistis dan akomodatif. ${ }^{28}$

Aktivitas ekonomi Islam pada masa ini lebih diletakkan sebagai kepentingan politik untuk mendukung keberlangsungan pembangunan negara, bukan semata-mata untuk berkembangnya entrepeneurship Muslim. Soeharto mengutip pentingnya Kurban dan Zakat ${ }^{29}$ seperti yang dijelaskan dalam al-Quran, namun lebih pada dukungan keagamaan secara sosial.

Mengingatkan kita pada masa pemerintahan Kolonial, kedekatan Soeharto dengan pengusaha keturunan Cina pada masa pemerintahannnya sangat kuat. Kritik dari Lembaga Swadaya Masyarakat dan Ormas Islam pada tahun 1980an gencar dilontarkan terutama dengan dominasi (konglomerasi) pengusaha keturunan Cina daripada Muslim (pribumi). ${ }^{30}$ Sebagai minoritas dengan jumlah penduduk tidak lebih dari 2,5 persen dari total penduduk

${ }^{27}$ Terdapat tiga katagori utama program politik pembangunan Orde Baru. Pertama, menjamin keberlangsungan hukum dan keamanan (stabilitas politik); kedua, merehabilitasi ekonomi yang terpuruk pada masa Soekarno (Orde Lama 1945-1965); ketiga, menyiapkan rencana pembangunan nasional. Muhammad Ali, "Islam and Economic Development in New Order's Indonesia (19671998)," dipresentasikan pada International Graduate Student Conference Series di East West Center Working Papers, No. 12, 2004, h. 5.

${ }^{28}$ Lihat Bahtiar Effendy, "Islam and State: The Transformation of Islamic Political Ideas dan Practices in Indonesia" (Ph.D. Dissertation: The Ohio State University, 1994); Ali, Islam and Economic Development, h. 9. Pernyataan ini seperti disampaikan pada peringatan Nuzul al-Quran 11 September 1976. Demikian juga dalam forum Majlis Dakwah Islamiyah Keluarga Besar Golongan Karya 13 Agustus 1979. Menurutnya, "Agama dan Pancasila tidak perlu dipertentangkan."

${ }^{29}$ Asep Saepudin Jahar,"The Clash of Muslims and the State: Waqf and Zakat in the Post Independence Indonesia," dalam Journal Studia Islamika, No. 13, 2006. Dalam kenyataannya Soeharto secara tidak langsung menolak untuk menjadi inisiator sekaligus pendorong gerakan zakat. Bahkan pada tahun 1991 Munawir Sjadzali pernah menawarkan kembali Soeharto untuk menjadi amil zakat nasional, namun kembali ditolaknya.

${ }^{30}$ Lihat Ali, Islam and Economic Development, h. 12. Lihat juga M. Dawam Rahardjo, "Islam dan Pembangunan: Agenda Penelitian Sosial di Indonesia," dalam Saiful Muzani (ed.), Pembangunan dan Kebangkitan Islam di Asia Tenggara (Jakarta: Pustaka LP3ES, 1993), h. 269-270. 
Indonesia, kelompok Cina menguasai 70-75 persen total perusahaan berskala menengah dan besar. ${ }^{31}$ Jika pada masa penjajahan, pengusaha Cina menjadi partner dalam bisnis dan penyediaan barang-barang yang dibutuhkan Kolonial Belanda, maka pada masa pemerintahan Soeharto kelompok Cina diposisikan sebagai pendorong pembangunan di segala sektor, salah satunya perbankan. Lahirnya BMI (Bank Muamalat Indonesia) salah satunya juga sebagai respons terhadap dominasi Cina dalam perbankan dan bisnis lainnya disamping dorongan motivasi teologis pemberlakuan sistem keuangan Islam yang bebas bunga.

Secara politis, komunikasi MUI (Majelis Ulama Indonesia) dengan pemerintahan Orde Baru sering menyentuh isu ekonomi, walaupun dalam realisasinya tidak mendapat ruang yang berarti. Saran atau nasihat yang utama lebih pada kegiatan zakat, bukan ekonomi pada umumnya. Karena itu secara organisatoris, MUI tidak memiliki kerangka pengembangan ekonomi Islam. ${ }^{32}$

Pada tahun 1991 secara simbolis Bank Muamalat Indonesia (BMI) didirikan sebagai satu-satunya bank Islam yang mempraktikkan bebas riba mendapat dukungan penuh Soeharto. Pendirian BMI diawali lebih dulu 1990 dengan pendirian Ikatan Cendekiawan Muslim Indonesia (ICMI) di Surabaya yang dipimpin langsung BJ Habibie. Peran MUI juga terlihat kemudian dalam pendirian Badan Penggerak Ekonomi Umat (BPEU). ${ }^{33}$ Perdebatan tentang haram dan halal bunga bank telah lama berlangsung, baik di NU, Muhammadiyah dan MUI. ${ }^{34}$ Namun akhirnya kemampuan umat Islam untuk mendirikan bank dengan basis syariah bisa tercapai pada tahun 1990 dengan keterlibatan politik Soeharto. Di sinilah peran penting kekuatan politik dan ekonomi menjadi bagian yang sangat penting dalam gerakan ekonomi Islam Indonesia.

Pada awal 1990, dengan dukungan Soeharto dan Habibie dengan ICMInya, momentum pendirian Bank Muamalat Indonesia (BMI) ini bersamaan dengan pertumbuhan pesat ekonomi Indonesia di atas 7\% sehingga menimbulkan kesadaran masyarakat Muslim untuk mengembangkan bisnis bersandar pada sistem keuangan Islam. Gerakan ekonomi

\footnotetext{
${ }^{31}$ Robert W. Hefner, "Islamisasi Kapitalisme: tentang Pembentukan Bank Islam Pertama di Indonesia," dalam Mark R. Woodward (ed.), Jalan Baru Islam (Bandung: Mizan, 1998), h. 255281.

${ }^{32}$ MUI lebih pada kegiatan formalitas dan himbauan seperti tentang makanan halal, dan sensor film. Lihat Ali, Islam and Economic Development, h. 15. Lihat juga, Darul Aqsha, Dick van der Meij dan Johan Hendrik Meuleman, Islam in Indonesia: A Survey of Events dan Developments from 1988 to 1993 (Jakarta: INIS, 1995), h.. 2221.

${ }^{33} \mathrm{Ali}$, Islam and Economic Development, h. 16.

${ }^{34}$ Lihat catatan Hefner tentang kritik keterlibatan NU dalam perbankan konvensional. Lihat misalnya Infobank 124 (April 1990) h. 12-13 yang merilis "Ketika Kiyai Bisnis Uang." Dalam laporan ini disebutkan bahwa NU menyalurkan kredit-kreditnya kepada kalangan Nahdliyyin. Misbach Mustofa, direktur pesantren al-Balal Rembang, Jawa Tengah juga memberikan kritik keras tentang inisiatif bank NU. Peran Gus Dur (Abdurrahman Wahid) dalam memobilisasi NU terlibat dalam perbankan dikritiknya sebagai manipulasi yang dilakukan para kapitalis Cina, Hefner, "Islamisasi Kapitalisme: tentang Pembentukan Bank Islam," h. 362. Lihat juga Hefner, "Islamisasi Kapitalisme: Tentang Pembentukan Bank Islam,” h. 261.
} 
Islam ini disamping dorongan sosial, ekonomi dan politik dari dalam juga adanya pengaruh luar seperti Revolusi Islam Iran 1979 dan pendirian Islamic Development Bank (IDB) tahun 1973. Seperti halnya pendirian ICMI yang dimotori para intelektual Muslim teknokrat dari universitas-universitas umum, bukan kalangan Perguruan Tinggi Islam semacam IAIN, kebangkitan ekonomi Muslim juga berlangsung dari komunitas kampus ITB dengan kegiatan keislaman Masjid Salman-nya.

Sebagai pusat kegiatan mahasiswa di luar kegiatan akademik, Masjid Salman menjadi tempat asosiasi para mahasiswa dan alumni Institut Teknologi Bandung (ITB). Dari Salman ini muncul gagasan pendirian koperasi yang berbasis ajaran Islam untuk menyiasati belum adanya aturan perbankan bebas bunga. Sistem koperasi ini didesain tetap mengacu pada aturan koperasi yang ada. Koperasi ini, dalam praktiknya, kemudian menjadi semacam lembaga finansial yang menyediakan pinjaman/simpanan untuk para pengusaha kecil. Lembaga ini disebut dengan Baitut Tamwil Teknosa atau koperasi Teknosa berdiri 4 Juli 1984. ${ }^{35}$ Seperti halnya koperasi, lembaga ini menerima simpanan suka rela dari para anggotanya dan kontribusi dari luar. Para penabung juga menerima laba dari simpanannya sesuai dengan lamanya simpanan. Dana yang dihimpun di koperasi ini digunakan untuk membiayai usaha dengan sistem patungan (musyârakah) dan kemitraan modal (mudhârabah) serta pengaturan kredit pengadaan barang (murâbahah dan al-bay'bi tsaman 'ajil). Sistem ini mencirikan pembiayaan berbasis muamalat Islam seperti halnya bank Islam. ${ }^{36}$

Cara kerja koperasi ini adalah sebagai berikut. Peminjam mendapatkan modal atau pembiayaan sesuai dengan kerangka pinjaman yang dipilih (musyârakah, mudhârabah atau bay 'bi tsaman 'ajil). ${ }^{37}$ Sistem koperasi Islam ini kemudian diadopsi dan dikembangkan di Jakarta oleh Adi Sasono, sebagai salah seorang mantan aktivis Salman ITB. Tepatnya tahun 1988 Koperasi Ridho Gusti dengan mengadopsi sistem koperasi Teknosa ITB didirikan di Jakarta. Koperasi ini beranggotakan 126 orang dan fokus pengembangan usahanya dalam pembiayaan usaha berskala kecil dan menengah.

Berbeda dengan gerakan ekonomi Islam di atas yang lebih bersifat terisolir dari pemerintah karena politik pemerintah Orde Baru terhadap Islam, pada paro awal 1990an kebijakan mulai berubah. Perubahan sikap Orde Baru ini menjadi momentum kebangkitan

${ }^{35} \mathrm{Ali}$, Islam and Economic Development, h. 16.

${ }^{36}$ Hefner, "Islamisasi Kapitalisme: tentang Pembentukan Bank Islam," h. 263.

${ }^{37}$ Dawam Rahardjo, Ekonomi Politik Pembangunan (Jakarta: LSAF, 2012), h. 3-32. Dalam uraiannya, Dawam melihat bahwa sistem musyârakah dan mudhârabah memerlukan kontrol yang ketat sehingga menambah biaya operasional dibanding cara-cara murâbahah atau bunga yang dipraktikkan di bank konvensional. Kontrol ini terutama dibutuhkan untuk menghindari moral hazard peminjam. Kritik Dawam ini banyak benarnya, karena pada kenyataannya praktik perbankan Islam saat ini lebih menonjolkan murâbahah, sistem pembiayaan dengan model jual beli dimana peminjam kemudian mengembalikan barang secara angsuran. Di sinilah praktik perbankan Islam dikritik sebagai lebih simbolik saja, karena marjin/keuntungan yang dicapai mirip dengan perbankan konvensional. 
ekonomi Islam yang diawali dari ICMI dan Bank Muamalat Indonesia. Posisi Majelis Ulama Indonesia, yang sering dikritik sebagai kepanjangan tangan pemerintah ${ }^{38}$ berperan penting dalam pendirian BMI. Menurut catatan Hefner, hasil wawancaranya dengan aktivis Muslim, inisiasi pendirian Bank Islam telah lama digagas MUI, yaitu sekitar tahun 1980an. Melihat kebijakan Orde Baru yang mulai bersahabat dengan Islam dari sisi non-partai Islam, MUI menggagas kembali rencana pendirian Bank Islam. Upaya MUI ini diawali kembali dengan mengadaan lokakarya pada tahun 1990 tentang "Masalah Bunga Bank dan Perbankan." Dalam forum ini yang diadakan pada 19-22 Agustus 1990 di Safari Garden Hotel Cisarua Bogor, MUI mendiskusikan prinsip-prinsip perbankan Islam dengan menghadirkan para ulama dan ahli perbankan. Para pejabat tinggi Bank Indonesia (BI), dewan moneter serta Departemen Keuangan hadir dalam lokakarya ini. Bertindak sebagai pembicara saat itu yaitu Prof. KH. Ibrahin Husen dari MUI, Karnaen Perwataatmadja mantan Direktur Eksekutif IDB (Departemen Keuangan RI), M. Dawam Rahardjo, ekonom dan pejabat dari Bank Indonesia. Lokakarya ini dihadiri oleh 165 peserta dari berbagai ormas Islam, pejabat pemerintah dan akademisi. ${ }^{39}$

Dari berbagai analisis kajian tentang Islam dan politik Indonesia, sikap Soeharto yang memberikan ruang pada umat Islam pada paro awal 1990an disebut sebagai masa kompromis dan akomodasi Islam sebagai kekuatan politik pemerintahannya. ${ }^{40}$ Pada masa itu, kekuatan politik Soeharto dengan tiga sayapnya, Golkar, Birokrasi dan ABRI mulai melemah dan karena itu ia membutuhkan kekuatan lain, yaitu kelompok Islam. Rencana pendirian bank Islam bukan tanpa halangan, bahkan penentangan itu datang dari Departemen Keuangan, senior angkatan darat dan badan intelejen. Alasan utamanya adalah bahwa pendirian bank Islam akan menimbulkan sektarianisme primordial. Pendirian ICMI dan BMI ini relatif bersamaan sebagai hasil "kerja politik" bersama pejabat pro-Islam di pemerintahan. Maka itu para tokoh dan penggagas rencana ICMI juga menjadi bagian dalam BMI. Inilah awal sikap akomodatif Soeharto yang sangat fenomenal terhadap umat Islam yang belum pernah terjadi dalam pemerintahan Orde Baru. ${ }^{41}$

\footnotetext{
${ }^{38}$ Kritik yang sering ditujukan kepada MUI yaitu sebagai mekanisme korporatis untuk mengkooptasi para ulama untuk menjalankan kepentingan pemerintahan Orde Baru. Hefner, "Islamisasi Kapitalisme: tentang Pembentukan Bank Islam," h. 264.

${ }^{39}$ Majelis Ulama Indonesia, "Keputusan dan Makalah Lokakarya Bunga Bank dan Perbankan, 1990." Lokakarya ini menghasilkan rekomendasi kepada dua kelompok. Pertama, kepada MUI yaitu perumusan konsep bank bebas bunga, pengembangan SDM, perintisan Baitul mal nasional, melakukan kerjasama dengan perguruan tinggi dan Lembaga Penelitian. Kedua, kepada pemerintah yaitu membuat diversifikasi produk perbankan yang bebas bunga dan pembukaan sistem bank baru dengan sistem bebas bunga, serta penghimpunan dana ziswaf. Kesimpulan dalam rapat sidang penutup lokakarya yaitu dipimpin oleh KH. Hasan Basri dan sekretaris Dr. Ir. M. Amin Aziz.

${ }^{40}$ Hefner, "Islamisasi Kapitalisme: tentang Pembentukan Bank Islam," h. 265. Lihat juga Bahtiar Effendy, Islam dan Negara (Jakarta: 2005). Lihat juga R. William Liddle, "Indonesia's Democratic Past and Future," dalam Comparative Politics 24, No. 4 (July 1992).

${ }^{41}$ Hefner, "Islamisasi Kapitalisme: tentang Pembentukan Bank Islam," h. 266. Lihat juga catatan kaki No. 21. Hefner menyimpulkan sikap Soeharto seperti ini sebagai hasil kajiannya dengan
} 
Kekuatan politik dalam memobilisasi gerakan ekonomi Islam sangat jelas dari kasus BMI dan kemudian gerakan zakat tahun 1999 dengan diundangkannya UU No. 38 tahun 1999 tentang Pengelolaan Zakat pasca kejatuhan Soeharto. Untuk membaca pada kasus pertama, BMI, keterlibatan politik Soeharto menjadi jalan pendirian bank Islam ini. Ganjalan modal pertama sesuai aturan Departemen Keuangan Rp 10 Milyar sebagai izin operasi, lagi-lagi mendapat dukungan penuh Soeharto. Dalam pendirian BMI, secara pribadi Soeharto menyumbangkan Rp 50 Juta, mengizinkan penggunaan dana Rp 3 Milyar dari Yayasan Amal Bhakti Muslim Pancasila dan sisanya sekitar Rp 7 Milyar dia akan mengadakan pertemuan 3 November 1991 untuk menggalang dana dari para pejabat, pengusaha dan warga Muslim untuk membeli saham BMI. ${ }^{42}$ Para pengusaha Muslim seperti Aburizal Bakri, Fadel Muhammad dan Fahmi Idris mendukung pendirian bank Islam ini. Didirikan pada 1 November 1991, BMI ditandatangani oleh lebih dari 30 pejabat dan pebisnis Muslim. Empat bank Islam ikut mendukung BMI yaitu, Bank Islam Faisal dari Mesir, al-Barakah dari Saudi Arabia, Bank Islam Berhard Malaysia dan Dharmal al-Islami dari Swiss. ${ }^{43}$

Pada tanggal 19 Maret 1991 Menteri Dalam Negeri Jenderal Rudini dan Menteri Agama Munawir Sjadzali menandatangani surat keputusan bersama pendirian BAZIS melalui pengawasan pemerintah. ${ }^{44}$ Pada awalnya pendirian Bazis ini meminta langsung Presiden Soeharto bertindak sebagai amil zakat nasionalnya, namun ia menolaknya.

Sebagai Ketua Umum ICMI, BJ. Habibie mencoba mengundang para pengusaha Muslim untuk membeli saham BMI. Dalam pertemuan yang dihadiri sekitar 87 pengusaha Muslim yang sengaja diundang ke Hotel Sahid pada 13 Oktober 1991, tercapai komitmen sebesar Rp 86 miliar untuk membeli saham BMI. Dalam enam minggu pertama pendirian BMI, terkumpul dana sekitar Rp 110 miliar, menempati posisi 35 besar bank Islam dari 56 bank Islam di dunia. Mobilisasi dana ini ternyata tidak seutuhnya mencerminkan dana bersih dari hasil usaha atau investasi para pengusaha Muslim. Disebutkan bahwa sekitar Rp 2 miliar dari total Rp 10 miliar diperoleh dari SDSB (Sumbangan Dana Sosial Berhadiah), semacam lotere dalam pembelian kupon untuk kegiatan sosial dan olah raga. Praktik SDSB, pada awal pendiriannya juga mendapat tentangan dari kaum Muslim juga dari MUI. Namun, setelah diketahui dana itu didapat dari SDSB, sepuluh hari kemudian pihak BMI mengembalikannya ke kantor SDSB. ${ }^{45}$

melakukan wawancara dengan para tokoh seperti M. Dawam Rahardjo, Wardiman dan Imaduddin Abdurrhim pada pertengahan 1992.

${ }^{42}$ Hefner, "Islamisasi Kapitalisme: Tentang Pembentukan Bank Islam," h. 267.

${ }^{43} \mathrm{Ali}$, Islam and Economic Development, h. 17

${ }^{44}$ Lihat juga catatan Muhammad Ali yang dikutip dari Darul Aqsha, Dick van der Meij dan Johan Hendrik Meuleman, Islam in Indonesia: A Survey of Events, h. 181-83.

${ }^{45}$ Hefner, "Islamisasi Kapitalisme: tentang Pembentukan Bank Islam," h. 268. Kepercayaan seperti ini beralasan jika melihat perkembangan bank Islam pada tahun 2000an, di mana bankbank konvensional berlomba-lomba untuk membuka unit usahanya dengan prinsip bank Islam. Terlepas lebih pada tujuan bisnis karena peluang pasar, kehadiran bank Islam, yang pada awalnya 
Tabel. 1

\begin{tabular}{|l|l|c|c|c|}
\hline No & \multicolumn{1}{|c|}{ Jenis Bank } & Tahun & Jumlah & Kantor \\
\hline 1 & Bank Konvensional & 2011 & 109 (termasuk 24 Unit Usaha Syariah) & 14.343 \\
\hline 2 & Bank Syariah & 2011 & 11 & 2.262 \\
\hline 3 & BPR & 2011 & 1.653 & 4.425 \\
\hline 4 & BPRS & 2012 & 160 & 399 \\
\hline
\end{tabular}

Gambaran tabel di atas (tabel 1) menunjukkan perkembangan yang berarti dilihat dari masa awal berdirinya BMI tahun 1992. Jumlah bank umum pada periode 2011, yaitu sebanyak 120 bank, yang terdiri dari 109 bank konvensional (termasuk 24 unit usaha syariah - UUS) dan 11 bank syariah. Jika dilihat dari jumlah kantor, terdapat 16.625 kantor bank yang terdiri dari 14.343 kantor bank umum konvensional (BUK) dan 2.262 kantor bank umum syariah (BUS). Sementara itu, jumlah BPR mencapai 1.653 bank dengan jumlah kantor mencapai 4.425 kantor. Jika dilihat berdasarkan pola penyebarannya, sebagian besar lokasi kantor, baik bank umum maupun BPR, masih terkonsentrasi di wilayah Jawa dan Sumatera. Sebanyak 74\% kantor bank umum berada di wilayah Jawa dan Sumatera dan 26,0\% kantor bank umum berada di luar Jawa dan Sumatera. Mayoritas BPR, dengan jumlah kantor yang mencapai 3.821 unit, tersebar di wilayah Jawa dan Bali. ${ }^{46}$ Sejalan dengan perbankan konvensional, fokus pembiayaan perbankan syariah ke sektor produktif mulai menunjukkan hasil. ${ }^{47}$

\section{Institusionalisasi Zakat Masa Orde Baru}

Dalam kasus zakat, upaya institusionalisasi dan nasionalisasi telah digagas pembentukan BAZNAS pada 10 Januari 1968 atas inisiasi MUI dengan tokoh utamanya Buya Hamka. Tanggal 26 Oktober 1968, dalam peringatan Isra' dan Mi'raj Soeharto menawarkan diri menjadi amil zakat nasional yang diikuti oleh keluarnya surat perintah (No. 07/PRIN/ 10/1968) tentang Bantuan Administrasi Penerimaan Zakat. ${ }^{48}$ Kesediaan Soeharto untuk menjadi amil zakat pada masa itu sebagai upaya simpati dari umat Islam setelah kejatuhan

dikhawatirkan pihak militer Orde Baru mematahkan tesis ini. Bank Islam tidak lagi dianggap sebagai ekspresi keagamaan tetapi lebih pada peluang bisnis dan pasar. Untuk membuktikan orientasi para pelaku bisnis, penelitian tentang preferensi nasabah dan pelaku bisnis terhadap bank Islam lebih didorong oleh faktor ekonomi, selanjutnya relijiusitas.

${ }^{46}$ Laporan Perekonomian Indonesia tahun 2012, BI tahun 2012, h. 143,

${ }^{47}$ Ibid., h. 144

${ }^{48}$ Amelia Fauzia, "Bazis DKI Jakarta: Peluang dan Tantangan BAZ Pemerintah Daerah," dalam Chaidir S Bamualim dan Irfan Abu Bakar (ed.), Revitalisasi Filantropi Islam (Jakarta: Pusat Bahasa dan Budaya, 2005), h. 32-33. Lihat juga Asep Saepudin Jahar, "The Clash of Muslims and the State: Waqf and Zakat in the Post Independence Indonesia," dalam Journal Studia Islamika, No. 13, 2006. 
Orde Lama (Soekarno). Dampak dari kesediaan Soeharto saat itu, walaupun sikapnya masih menyisakan multitafsir, didirikan Badan Amil Zakat di daerah-daerah, seperti Aceh, Kalimantan, Jawa Tengah, Jawa Timur dan Sumatera Barat. Secara formal, sinyal positif kesediaan Soeharto ini tak pernah diwujudkan secara nasional, kecuali memberikan ruang kebebasan kepada pemerintahan daerah untuk berinisiatif mendirikan ZIS masing-masing.

Sebagai respons gerakan zakat ini Ali Sadikin, Gubernur DKI mengeluarkan SK No Cb/14/8/18/68 tanggal 5 Desember 1968 tentang Pembentukan Badan Amil Zakat DKI. ${ }^{49}$ Di DKI Jakarta perkembangan Badan Amil Zakat cukup menonjol sehingga 1973 berubah nama menjadi Badan Amil Zakat, Infaq dan Shadaqah untuk bisa menjangkau dana amal yang lebih luas. ${ }^{50}$ System pengelolaan zakat di DKI dimulai dari tingkat kelurahan, kecamatan, walikota dan Gubernur, masing-masing bertindak sebagai ketua Bazis dari unsur pemerintah. Struktur ini tetap berlaku hingga saat ini sejak masa berdirinya dari tahun 1968.Yang menarik dari pengelolaan BAZIS DKI yaitu, staff yang diperbantukan dari pemerintah DKI menerima gaji dari pemda, bukan dari hasil ZIS. Demikian juga pemerintah memberikan dana operasional setiap tahunnya.

Mengikuti jejak DKI Jakarta yang telah mendirikan BAZnya tahun 1968, Gubernur Propinsi Jawa Barat mengeluarkan SK Gubernur Kepala Daerah Tingkat I no. 352/H.I/ 3/Sk/1974 pada tanggal 1 Oktober 1974 tentang pendirian BAZ yang berwenang mengelola zakat di Jawa Barat. ${ }^{51}$

Gerakan zakat di Aceh juga ditetapkan secara resmi oleh pemerintah daerah tahun 1968 melalui surat keputusan gubernur no. 11/1968, no. 452/DKDA/1968 dan no. 180/ MU/1968 pada 28 November 1968. Isi instruksi ini antara lain, memerintahkan kepada para pimpinan daerah mulai dari bupati dan camat untuk bekerja sama dengan KUA untuk mendirikan lembaga zakat. Upaya pengembangan zakat ini terus dilakukan hingga pada 28 November 1988 dibuat lembaga Badan Pembina dan Musyawarah Amil Zakat, Infaq dan Sadaqah dengan tujuan untuk meningkatkan pengumpulan zakat, infaq dan shadaqah

${ }^{49}$ Lihat catatan Amelia tentang dinamika sosial politik pembentukan zakat di Indonesia yang menjadi bagian sistem negara. Baitul Mal tahun 1938 pernah digagas oleh MIAI, dan gerakan zakat di beberapa daerah seperti Aceh. Penjelasan detail tentang ini dapat dilihat, menurut kutipan Amelia Fauzia seperti BJ Boland, the Struggle of Islam in Modern Indonesia (The Hague: Martinus Nijhoff, 1971), juga lihat Taufik Abdullah,"Zakat Collection and Distribution in Indonesia," dalam Muhammad Ariff (ed.), Islam and the Economic Development of Southeast Asia: The Islamic Voluntary Sector in Southeast Asia (Pasir Panjang, Singapore: ISEAS, 1991).

${ }^{50}$ BAZIS DKI Jakarta memilik visi "menjadi badan pengelola ZIS yang terunggul dan terpercaya." Misinya yaitu, "mewujudkan optimalisasi pengelolaan ZIS yang amanah, professional, transparan, akuntabel dan mandiri di propinsi DKI Jakarta menuju masyarakat yang sejahtera, berdaya dan bertaqwa." Fauzia, "Bazis DKI Jakarta: Peluang dan Tantangan BAZ Pemerintah Daerah," h. 35 .

${ }^{51}$ Sudjangi, "Organisasi dan Pengelolaan Zakat Fitrah di Jawa Barat," dalam Sudjangi (ed.), Kajian Agama dan Masyarakat (Jakarta: Badan Penelitian dan Pengembangan Agama, 1992/1993), h. 145. 
dari masyarakat. Namun usaha gerakan zakat di Aceh mengalami hambatan dengan adanya konflik kepentingan para ulama yang telah lama menikmati manfaat zakat dan shadaqah. Kehadiran lembaga ZIS pemerintah dianggap sebagai penghalang pemasukan rutin para ulama dari ZIS yang telah berlangsung lama. ${ }^{52}$

Lembaga ini dikontrol langsung oleh gubernur dan kepala wilayah departemen agama di propinsi. Setiap pegawai negeri diwajibkan bayar zakat dengan cara pemotongan dari gaji secara langsung, terutama dengan penghasilan Rp 186.000 dengan potongan ratarata 2.5 persen. Sedangkan mereka yang berpenghasilan lebih rendah, potongannya yaitu 1 persen setiap bulan. Hasil zakat yang terkumpul dibagikan kepada kelompok miskin yaitu 65 persen bagi fuqara, pengelola zakat dan sabilillah; 20 persen disalurkan ke kecamatan; 10 dan 5 persen didistribusikan untuk kabupaten/kota dan propinsi. ${ }^{53}$

Sistem pengelolaan zakat, selain dilakukan oleh pemerintah juga dikelola oleh para ulama yang bekerja sama dengan perusahaan swasta daerah, seperti PT Arun Naturan Gas Company, perusahan besar yang bergerak dalam penambangan gas di Aceh. Pada saat itu sekitar tahun 1985-1987 dan 1988-1989 jumlah total zakat yang terkumpul mencapai Rp 64.576.925. ${ }^{54}$

\section{Filantropi Islam Kontemporer}

Aktivitas filantropi Islam di Indonesia telah lama hidup bersamaan dengan masuknya Islam ke Indonesia. Wakaf, zakat, infaq dan sedekah adalah model filantropi yang berkembang di masyarakat. Ironisnya, aktivitas dana amal ini belum memberikan pengaruh yang berarti jika dibanding dengan jumlah penduduk Muslim lebih dari 200 juta orang. Hal ini tidak lepas dari pengaruh doktrinal, sosial dan politik yang berlangsung.

Pasca 1990an dan 2000an, setelah lahirnya UU No. 38 tahun 1999 tentang Pengelolaan Zakat dan perubahannya menjadi UU No. 23 tahun 2011 dan UU No. 41 tahun 2004 tentang Wakaf, geliat aktivitas ini sangat terasa di berbagai organisasi non-pemerintah dan pemerintah melalui BAZ (Badan Amil Zakat). Lembaga Amil Zakat (LAZ) dapat ditemukan di setiap daerah. Namun kita perlu melihat bagaimana upaya politik ini mengalami liku-liku beberapa fase perkembangannya. ${ }^{55}$

${ }^{52}$ Asep Saepudin Jahar, Toward Reforming Islamic Philanthropy: Case Study of Waqf and Zakat in Contemporary Indonesia (Leipzig: Universitaet Leipzig, 2005), h. 160-161.

${ }^{53}$ Jahar, Toward Reforming Islamic Philanthropy, h. 161.

${ }^{54}$ Sistem pengelolaan zakat di Aceh mengalami hambatan di masyarakat, terutama karena peran ulama yang cukup dominan dalam aspek ini. Karena itu upaya pemerintah dalam pengelolaan zakat kurang mendapat dukungan; bahkan masyarakat masih memperdebatkan eksistensi pemerintah dalam pengelolaan zakat. Kecenderungan para ulama, zakat dikelola oleh masyarakat terutama ulama. Di sini terlihat bahwa zakat telah menjadi sumber pendapat yang berarti bagi para ulama. Jahar, Toward Reforming Islamic Philanthropy, h. 162-163.

${ }^{55}$ Sukron Kamil, "Baitul Mal BMT Ben Taqwa Grobogan: Pola Manajemen ZIS untuk Usaha 
Cara kerja BMT serupa dengan koperasi, yaitu suka rela dengan menerapkan simpanan pokok dan sukarela dapat didirikan dengan jumlah anggota minimal 20 orang. Yang membedakannya adalah sistem syariah, terutama bagi hasil menjadi praktik utama dalam usahanya. Akad-akad yang umum dipraktikkan yaitu, musyârakah (usaha kongsi) penyertaan modal, mudhârabah (bertindak menjalan usaha dari modal BMT dikenal dengan mudhârib) dan murâbahah (akad jual beli dengan pembayaran melalui sistem angsuran). ${ }^{56}$ Tujuan BMT yaitu sosial dan ekonomi untuk pemberdayaan kualitas ekonomi masyarakat, dan menghindari dari praktik rentenir yang merugikan masyarakat. Sebab itu sistem pinjaman BMT tidak menggunakan agunan dan bunga, tetapi bagi hasil atau qardh al-hasan, mengembalikan pinjaman hanya modal pokoknya saja. Pinjaman yang bersifat qardh al-hasan biasanya diambil dari dana ZIS. Dapat dikatakan bahwa sistem BMT lebih merakyat dan menjangkau pedesaan dari pada Bank Syariah. Karena posisinya yang berdampingan dengan masyarakat bawah, BMT bisa menyentuh masyarakat usaha kecil yang belum mampu mengajukan proposal pinjaman kepada bank-bank besar seperti Bank Muamalat Indonesia.

Seperti halnya lembaga zakat, BMT juga menerima dan menyalurkan dana ZIS baik dari lembaga zakat lainnya atau yang dihimpun secara mandiri. Dana ZIS digunakan untuk qardh al-hasan (pinjaman lunak dimana nasabah hanya mengembalikan modal pokoknya saja). Prinsip qardh al-hasan, yaitu bantuan semata dan dana ini bisa bergulir ke nasabah lainnya. Disamping penyaluran dana, BMT juga berperan dalam penguatan sosial keagamaan, dimana para nasabah yang menjadi mitra BMT mendapatkan bimbingan keagamaan dan pengayaan kehidupan spiritualnya. ${ }^{57}$

\section{Kelahiran BAZ dan LAZ}

Pada periode inilah LAZ berdiri di berbagai tempat dan hingga saat ini telah didirikan

Ekonomi dan Pendidikan Mustahik," dalam Chaidir S Bamualim dan Irfan Abu Bakar (ed.), Revitalisasi Filantropi Islam, (Jakarta: Pusat Bahasa dan Budaya, 2005), 127. Dilihat juga catatan kaki 3 dalam penjelasan BMT yaitu Hertanto Widodo Ak. DK., Panduan Praktis Operasional BMT (Bandung: Mizan, 1999), h. 81-82. Juga PINBUK, Pedoman Cara Pembentukan BMT (Jakarta: PINBUK, t.t.), h. 2.

${ }^{56}$ Kamil, "Baitul Mal BMT Ben Taqwa Grobogan," h. 128. Lihat juga catatannya No. 9 dan 10, h. 143-144.

${ }^{57}$ Kamil, "Baitul Mal BMT Ben Taqwa Grobogan," h. 128-129. 
lebih dari $30 \mathrm{LAZ}^{58}$ yang mendapat izin resmi pemerintah diantara yang menonjol yaitu Dompet Dhu'afa dan PKPU (Pos Keadilan Peduli Umat). ${ }^{59}$

Sejak 2001, Dompet Dhuafa melepaskan diri dari Republika dan melakukan perubahan manajemennya.Tonggak perubahan manajemen modern DD diawali pada tahun 2003 dengan menfokuskan pada 4 program model jejaring. Pertama, Lembaga Amil Zakat (dipimpin oleh Hertanto Widodo), kedua jejaring Asset Reform (JAR) oleh Jamil Azzaini, ketiga Jejaring Aset Sosial dipimpin oleh Ahmad Juwaini dan keempat Business Development atau jejaring Komersial dipimpin oleh Rahmad Riyadi. Keempat jejaring ini dibawah kendali Rini Supri Hartini yang bertindak sebagai Vice President. ${ }^{60}$ Konsep jejaring ini diturunkan dari visi dan misinya. Visi DD yaitu Terwujudnya masyarakat berdaya yang bertumpu pada sumber daya lokal melalui sistem yang berkeadilan. Dan misinya: Membangun nilai kemanusiaan dan kemandirian; Meningkatkan partisipasi derma masyarakat dan dukungan sumber daya untuk pemberdayaan; Mendorong sinergi program dan jaringan organisasi pemberdayaan masyarakat global; Menumbuhkembangkan dan mendayagunaan aset masyarakat melalui ekonomi berkeadilan; Mengembangkan zakat sebagai alternatif dalam pengentasan kemiskinan. ${ }^{61}$

Dalam bidang ekonomi, pemberdayaan masyarakat melalui dana ZIS Dompet Dhuafa beragam. Model bantuan itu yaitu, bantuan pengembangan usaha tani bagi para petani, peternakan dan kelompok pedagang asongan. Untuk kasus peternakan, pengembangannya diawali pada domba (kambing) di daerah Garut, Sukabumi, Cianjur dan Bogor. Pada tahun 2003, kelompok peternak ini berhasil mengelola domba yang terdiri dari 49 ekor pejantan, 520 ekor induk, 71 anak pejantan dan 83 anak betina, ditambah 100 ekor domba yang digemukkan untuk bisa dipasarkan langsung. ${ }^{62}$ Pemberdayaan para pengasong dilakukan

${ }^{58}$ Lihat zakatonbc.wordpress.com. Diantara LAZ yaitu: Al-Azhar Peduli Umat di Jakarta, Amanah Takaful di Mampang Prapatan Jakarta, Baitul Mal Hidayatullah (BMH) di Jakarta, Baitul Mal Muamalat (BMM) di Jakarta, Baituzzakah Pertamina (Bazma) di Jakarta, BAMUIS Bank BNI di Jakarta, Baitul Mal Pupuk Kujang (BMPK) di Cikampek Jawa Barat, Baitul Mal Pupuk Kaltim di Bontang Kaltim, BPZIS Bank Mandiri, Jakarta, Bina Sejahtera Mitra Ummat di Jakarta, Dompet Dhuafa (DD) di Ciputat Tangsel, DPU Darut Tauhid Bandung, LAZ Ikatan Persaudaraan Haji Indonesia (LAZ IPHI), LAGZIS Malang Surabaya, LAZ al-Hijrah Medan, LAZ Yaumil PT Badak NGL Bontang Kaltim, LAZIS Muhammadiyah Jakarta, LAZ NU Jakarta, LAZNAS BMT Jakarta, Lembaga Manajemen Infaq (LMI) Surabaya, Portal Infaq Jakarta, PKPU Jakarta, Rumah Zakat Indonesia Bandung, Yayasan Dan Sosial al-Falah (YSDF) Surabaya, Yayasan Baitul Mal Bank BRI (YBM BRI) Jakarta dan LAZ Nurul Hayati Surabaya.

${ }^{59}$ Lihat Karlina Helmanita, "Mengelola Filantropi Islam dengan Manajemen Modern: Pengalaman Dompet Dhuafa," dalam Chaidir S Bamualim dan Irfan Abu Bakar (ed.), Revitalisasi Filantropi Islam (Jakarta: Pusat Bahasa dan Budaya, 2005), h. 90.

${ }^{60}$ Helmanita, "Mengelola Filantropi Islam dengan Manajemen Modern: Pengalaman Dompet Dhuafa," 94 lihat juga catatan kaki 19 tulisan ini dari S. Sinansari Ecip, Jejak-jejak Membekas (Jakarta: Cahaya Timur, 2003), h. 158.

${ }^{61}$ https://www.dompetdhuafa.org/profil/visi-misi/.

${ }^{62}$ Helmanita, "Mengelola Filantropi Islam dengan Manajemen Modern: Pengalaman Dompet Dhuafa," h. 112. 
di daerah Kramat Jati, dimana dari hasil investigasi DD, kondisi ekonomi pengasong tidak pernah berkembang, walaupun usaha mereka dalam berdagang sangat keras. DD menyiasati masalah ini yaitu dengan mendirikan grosir untuk para pengasong dan ditempatkan dalam suatu tempat secara gratis. Sistem yang dikembangkan yaitu bagi hasil dari keuntungan usaha, untuk pengembangan grosir dan sebagian lagi untuk pengasong. ${ }^{63}$

Selain Dompet Dhuafa, Lembaga Amil Zakat lain yaitu PKPU (Pos Keadilan Peduli Umat) didirikan secara resmi pada 8 Oktober 2001 melalui SK Menteri Agama RI No. 441 tahun 2001. Kehadiran PKPU sangat erat kaitannya dengan diundangkannya UU No. 38 tahun 1999 tentang Pengelolaan Zakat. Awalnya PKPU bernama Pos Terpadu Pelayanan Masyarakat (Poster Masyarakat), di bawah naungan Departemen Kesejahteraan Sosial (Depkessos) salah satu divisi Partai Keadilan, sebelum berubah menjadi Partai Keadilan Sejahtera pasca kegagalan mencapai electoral threshold dalam pemilu 1999. Ketika masih di bawah naungan PK, kegiatan Poster Masyarakat membantu korban konflik di Maluku Ambon dan Poso. Pada saat itu penghimpunan dana mencapai 3,5 miliar rupiah selama satu tahun. ${ }^{64}$

PKPU pada awalnya berdiri tanggal 10 Desember 1999 terdaftar dalam akta notaris sebagai yayasan terpisah dari unsur Partai Keadilan. Alasan pendirian lembaga ini adalah sebagai respons atas antusiasme masyarakat dalam membantu masyarakat dengan membantu orang lain karena faktor solidaritas dan kepercayaan. Kasus konflik yang terjadi di beberapa daerah belum mendapat penanganan pemerintah secara optimal. ${ }^{65}$ Visi lembaga ini yaitu "menjadi institusi terdepan di Indonesia dalam menebar peduli untuk kepentingan umat manusia dengan pengelolaan yang amanah dan profesional." Sebagai lembaga modern, PKPU menerapkan sistem manajemen berbasis ISO 9001/2000 sebagai lembaga yang menganut standar internasional. ${ }^{66}$

Program aktivitas PKPU serupa dengan program Lembaga Amil Zakat lainnya yaitu bidang sosial, ekonomi dan pendidikan masih menjadi fokus kegiatannya. Dalam bidang pendidikan, misalnya, pemberian beasiswa bagi pelajar yang berprestasi dan dhu'afa'. Di samping itu juga training bagi anggota masyarakat untuk peningkatan kemampuan (skil) usaha. Dalam bidang dakwah (sosial), kegiatannya yaitu penyiapan calon da'i yang akan terjun di daerah bencana dan masyarakat terpencil. Sedangkan dalam kesehatan, menyediakan klinik bagi masyarakat miskin berupa pelayanan kesehatan keliling. Demikian juga dalam

${ }^{63}$ Ibid., h. 112-113.

${ }^{64}$ Chaider S Bamualim dan Tuti A Najib, Pos Keadilan Peduli Umat (PKPU): Fenomena Educated Urban Muslim dan Revitalisasi Filantropi," dalam Chaidir S Bamualim dan Irfan Abu Bakar (ed.), Revitalisasi Filantropi Islam (Jakarta: Pusat Bahasa dan Budaya, 2005), h. 176

${ }^{65}$ Bamualim dan Tuti A Najib, "Pos Keadilan Peduli Umat (PKPU): Fenomena Educated Urban Muslim dan Revitalisasi Filantropi," h. 177.

${ }^{66}$ Pendekatan seperti ini menunjukkan bahwa biaya yang dikeluarkan untuk mendapat sertifikat manajemen ISO cukup besar. Artinya, dana zakat atau sumbangan sukarela dari masyarakat digunakan sebagai upaya daya tarik profesionalisme manajemen yang dibiayai oleh masyarakat juga sehingga meningkatkan kredibilitasnya di masyarakat. 
ekonomi, yaitu membantu memberdayakan ekonomi usaha kecil dengan memberikan bantuan lunak tanpa bunga atau training. ${ }^{67}$ Kegiatan-kegiatan ini didanai dari hasil zakat, infaq, shadaqah dan wakaf. Berikut adalah penerimaan dan penyaluran dana PKPU. ${ }^{68}$

Tabel 2

\begin{tabular}{|c|r|r|}
\hline Tahun & Penerimaan (Rp) & \multicolumn{1}{|c|}{ Penyaluran (Rp) } \\
\hline 1999 & $3.513 .016 .000,-$ & $3.513 .016 .000,-$ \\
\hline 2000 & $12.230 .014 .617,-$ & $10.791 .636 .196,-$ \\
\hline 2001 & $9.302 .529 .103,-$ & $8.568 .781 .656,-$ \\
\hline 2002 & $9.476 .536 .163,-$ & $9.645 .206 .904,-$ \\
\hline Total & $34.522 .095 .885,-$ & $32.518 .640 .666,-$ \\
\hline
\end{tabular}

Selama tahun 2006 hingga tahun 2012, total asset PKPU terus meningkat yaitu: Rp 24.083.514.317 (2006); Rp 30.955.652.942 (2007); Rp 33.001.865.491 (2008); Rp 41.401. 160.688 (2009); Rp 42.887.300.102 (2010); Rp 43.131.792.349 (2011); Rp 54.805.336.698 (2012). ${ }^{69}$ Dana yang terkumpul ini disalurkan melalui program kegiatan yang mencakup pendidikan, ekonomi, kesehatan, tanggap darurat, social dan yatim..$^{70}$ Dalam hal pendidikan, kegiatannya difokuskan pada sekolah berbasis komunitas yaitu melihat pada potensi dan kearifan local. Kegiatan ini dilakukan untuk melengkapi pendidikan formal.Disamping itu beasiswa juga menjadi bidikan program ini khususnya bagi masyarakat yang tidak mampu. Penguatan lainnya juga dengan perpustakaan keliling sebagai upaya meningkatkan minat baca masyarakat.Program bantuan untuk renovasi sekolah juga bagian dari program pendidikan. Kegiatan ini dilakukan bersama masyarakat.

Penyaluran dana PKPU yang lebih menonjol yaitu untuk tujuan kemanusiaan seperti untuk bantuan banjir dan koran konflik. Sebagai ilustrasi dana yang dihimpun dari 34,5 miliar rupiah sebanyak 20,2 miliar rupiah disalurkan untuk kemanusiaan, 6,7 miliar rupiah dari dana zakat, 4,2 miliar rupiah dari kurban dan 2,4 miliar rupiah infak dan shadaqah. Pendanaan juga diambil dari dana wakaf dan dana lain. ${ }^{71}$

\section{Penutup}

Gerakan ekonomi Islam mengalami perubahan orientasi dari masa awal kemerdekaan hingga saat ini.Misi gerakan masa awal lebih menonjolkan semangat nasionalisme dan

\footnotetext{
${ }^{67}$ Bamualim dan Tuti A Najib, "Pos Keadilan Peduli Umat (PKPU)," h. 182.

${ }^{68}$ Ibid.," h. 183,

${ }^{69}$ Sumber laporan www.pkpu.or.id.

${ }^{70}$ www.pkpu.or.id/program.

${ }^{71}$ Bamualim dan Tuti, "Pos Keadilan Peduli Umat (PKPU)," h. 187.
} 
keagamaan dengan melibatkan kelompok Islam dalam gerakan ini terutama diwakili oleh perwakilan-perwakilan ormas.Sarekat Islam adalah salah satu gerakan Islam yang bersifat terbuka dari kelompok etnik yang merespons diskriminasi kolonial terhadap pribumi.

Pada masa kemerdekaan hingga masa reformasi, gerakan ekonomi lebih menekankan entrepreneurship untuk pengembangan masyarakat. Semangat Islam juga menguat pada masa ini, terutama dalam menyikapi system kapitalisme yang dianggap tidak memberikan kondisi perbaikan sosial dan ekonomi masyarakat.Karena itu semangat pendirian bank syariah dan lembaga-lembaga filantropi Islam hadir sebagai kesadaran untuk mengembangkan masyarakat Muslim. Dalam perkembangannya, semangat keislaman ini melebur pada konteks demokratisasi yang menekankan transparansi dan akuntabilitas, bukan semata-mata keagamaan.Karena itu, model gerakan ekonomi diarahkan pada pemberdayaan masyarakat yang lebih bersifat public dan kesejahteraan.Di sinilah respons masyarakat dalam system ekonomi Islam lebih bersifat substansial dari pada simbolik keagamaan.

\section{Pustaka Acuan}

Abdullah, Taufik. "Zakat Collection and Distribution in Indonesia," dalam Muhammad Ariff (ed.), Islam and the Economic Development of Southeast Asia: The Islamic Voluntary Sector in Southeast Asia, Pasir Panjang, Singapore: ISEAS, 1991.

Ahmad, Wardini. “Kongres al-Islam 1922-1941.” Disertasi: Program Pascasarjana IAIN Syarif Hidayatullah, 1989.

Ali, Muhammad. "Islam and Economic Development in New Order's Indonesia (19671998)", dipresentasikan pada International Graduate Student Conference Series di East West Center Working Papers, No. 12, 2004.

Annual Report DD 2003.

APE Korver. Sarekat Islam Gerakan Ratu Adil?. Jakarta: Grafitipers, 1985.

Aqsha, Darul, et al. Islam in Indonesia: a Survey of Events dan Developments from 1988 to 1993. Jakarta: INIS, 1995.

B.J. Boland. The Struggle of Islam in Modern Indonesia. The Hague: Martinus Nijhoff, 1971.

Bamualim, Chaider S dan Tuti A Najib. "Pos Keadilan Peduli Umat (PKPU): Fenomena Educated Urban Muslim dan Revitalisasi Filantropi" dalam Chaidir S Bamualim dan Irfan Abu Bakar (ed.). Revitalisasi Filantropi Islam. Jakarta: Pusat Bahasa dan Budaya, 2005.

Ecip, S Sinansari. Jejak-jejak Membekas. Jakarta: Cahaya Timur, 2003.

Fauzia, Amelia. "Bazis DKI Jakarta: Peluang dan Tantangan BAZ Pemerintah Daerah," dalam Chaidir S Bamualim dan Irfan Abu Bakar (ed.). Revitalisasi Filantropi Islam. Jakarta: Pusat Bahasa dan Budaya, 2005.

Hasan, Pipip Achmad Rifai. "Islam, Social Justice and Economic Development: A Study of the Works of Sjafruddin Prawiranegara." Disertasi: Concordia University Montreal, 2012. 
Hefner, Robert W. "Islamisasi Kapitalisme: Tentang Pembentukan Bank Islam Pertama di Indonesia," dalam Mark R Woodward (ed.). Jalan Baru Islam. Bandung: Mizan, 1998.

Hijrah Hati, et al. "The Social Movement and Social Enterprise Development in the Emergence of Indonesia 1895-1945 in Univeristy of Malaya." t.t.p.: t.p., t.t.

Hiroshi, Mitsuo. The Development of Javanese Cotton Industry. Tokyo: The Institute of Developing Economics, 1970.

http://pusat.baznas.go.id/profil/

https://www.dompetdhuafa.org/profil/visi-misi/.

Jahar, Asep Saepudin. "The Clash of Muslims and the state: Waqf and Zakat in the Post Independence Indonesia," dalam Journal Studia Islamika, No. 13, 2006.

Jahar, Asep Saepudin. Toward Reforming Islamic Philanthropy: Case Study of Waqf and Zakat in Contemporary Indonesia. Leipzig: Universitaet Leipzig, 2005.

Kamil, Sukron. "Baitul Mal BMT Ben Taqwa Grobogan: Pola Manajemen ZIS untuk Usaha Ekonomi dan Pendidikan Mustahik," dalam Chaidir S Bamualim dan Irfan Abu Bakar (ed.) Revitalisasi Filantropi Islam. Jakarta: Pusat Bahasa dan Budaya, 2005.

Karlina Helmanita. "Mengelola Filantropi Islam dengan Manajemen Modern: Pengalaman Dompet Dhuafa," dalam Chaidir S Bamualim dan Irfan Abu Bakar (ed.). Revitalisasi Filantropi Islam. Jakarta: Pusat Bahasa dan Budaya, 2005.

Kuntowijoyo. Paradigma Islam. Bandung: Mizan, 1998.

Laporan Perekonomian Indonesia tahun 2012, BI tahun 2012.

Larson, George D. Masa Menjelang Revolusi. Yogyakarta: Universitas Gajah Mada, 1990.

Liddle, R William. "Indonesia's Democratic Past and Future," dalam Comparative Politics 24, No. 4 (July 1992).

Lombard, Denys. Nusa Jawa: Silang Budaya. Jakarta: Gramedia, 2008.

Mehden, F. V. D. (ed.). Oxford Bibliographies Online, Islamic Studies, 2009.

Najib, Tuti Alawiyah. "Baperlurzam Kendal: Gerakan Zakat Muhammadiyah," dalam Chaidir S Bamualim dan Irfan Abu Bakar (ed.). Revitalisasi Filantropi Islam. Jakarta: Pusat Bahasa dan Budaya, 2005.

Nakamura, Mitsuo. The Crescent Arises over the Banyan Tree. Yogyakarta: UGM, 1983.

Noer, Deliar. The Modernist Muslim Movement in Indonesia 1900-1942. Kuala Lumpur: Oxford University Press, 1978.

Pijper, G.F. Beberapa Studi tentang Sejarah Islam di Indonesia 1900-1950, terj. Tujimah dan Yessy Augusdin. Jakarta: UI Press, 1985.

Pinbuk. Pedoman Cara Pembentukan BMT. Jakarta: Pinbuk, t.t.

Rahardjo, Dawam. Ekonomi Politik Pembangunan. Jakarta: LSAF, 2012.

Rahardjo, M Dawam. "Islam dan Pembangunan: Agenda Peneliteian Sosial di Indonesia," dalam Saiful Muzani (ed.), Pembangunan dan Kebangkitan Islam di Asia Tenggara. Jakarta: Pustaka LP3ES, 1993. 
MIQOT Vol. XXXIX No. 2 Juli-Desember 2015

Statistik Perbankan Syariah 2013.

Sudjangi. Organisasi dan Pengelolaan Zakat Fitrah di Jawa Barat," dalam Sudjangi (ed.). Kajian Agama dan Masyarakat. Jakarta: Badan Peneliteian dan Pengembangan Agama, 1992/1993.

Widodo, Hertanto. Panduan Praktis Operasional BMT. Bandung: Mizan, 1999.

www.dompetdhuafa.org.

www.muhammadiyah.or.id

www.pkpu.or.id

www.pkpu.or.id/program

www.pkpu.or.id/program.

zakatonbc.wordpress.com.

www.kontan.co.id

www.ojk.go.id 